\title{
DAYA TERIMA DAN KANDUNGAN FLAVONOID SIRUP KOMBINASI BELIMBING WULUH (AVERRHOA BILIMBI L) DAN DAUN TIN (FICUS CARICA L) SEBAGAI MINUMAN ALTERNATIF ANTIOKSIDAN KAYA FLAVONOID
}

\author{
Level of Acceptance and Flavonoid Content of Syrup Made of Averrhoa bilimbi L and Ficus \\ carica L as an Alternative Antioxidants Drinks Rich in Flavonoid \\ Vetty Silvana Maulida ${ }^{*}$, Annis Catur Adi ${ }^{2}$ \\ ${ }^{1}$ Program Studi S1 Ilmu Kesehatan Masyarakat, Fakultas Kesehatan Masyarakat, Universitas Airlangga, Surabaya \\ ${ }^{2}$ Departemen Gizi Kesehatan, Fakultas Kesehatan Masyarakat, Universitas Airlangga, Surabaya, Indonesia \\ E-mail: vetty.silvana@gmail.com
}

\begin{abstract}
ABSTRAK
Belimbing wuluh (Averrhoa bilimbi L) dan tanaman tin (Ficus carica L) merupakan tanaman yang semua bagiannya mengandung banyak senyawa aktif diantaranya flavonoid pada bagian buah dan daun. Flavonoid bermanfaat sebagai antioksidan eksogen tubuh. Penelitian ini bertujuan menganalisis daya terima dan kandungan flavonoid sirup belimbing wuluh yang diformulasikan dengan penambahan daun tin. Penelitian ini merupakan penelitian eksperimen dengan Rancangan Acak Lengkap (RAL). Terdapat 4 kali pengulangan pada 4 formula yaitu 1 formula kontrol (F0) dan 3 formula modifikasi (F1, F2, F3). Penambahan daun tin pada F1 (100 g), F2 (150 g), dan F3 (250 g). Analisis data menggunakan Uji Friedman dan Wilcoxon Test $(\alpha=0,05)$. Hasil menunjukkan bahwa penilaian sirup dapat diterima secara umum (warna, aroma, tekstur, dan rasa) dengan kategori 3 (suka). Formula terbaik yaitu formula modifikasi 1 (F1) dengan penambahan daun tin paling sedikit, formula 1 (FI) lebih banyak disukai dari segi rasa. Penilaian antara F1 dengan formula modifikasi lain pada karakteristik warna tidak berbeda signifikan $(\alpha \quad 0,05)$, perbedaan terdapat pada aroma, tekstur, dan rasa ( $\alpha$ 0,05). Sirup kombinasi belimbing wuluh (Averrhoa bilimbi L) dan daun tin (Ficus carica $L$ ) dapat direkomendasikan sebagai minuman fungsional dengan kandungan flavonoid sebesar 0,233\% per $100 \mathrm{ml}$ sirup atau $233 \mathrm{mg}$ yang bisa mencukupi kebutuhan flavonoid tubuh dalam kondisi sehat maupun sakit seperti hiperkolesterolemia.
\end{abstract}

Kata kunci: belimbing wuluh, daun tin, daya terima, flavonoid, sirup

\begin{abstract}
Averrhoa bilimbi L and Ficus carica L contain many active compounds particularly flavonoid in all parts of the plant especially its fruits and leaves. Flavonoid can be used as exogenous antioxidants. This research was done to analyze the acceptance and flavonoid content of the formulated syrup of Averrhoa bilimbi L and Ficus carica Leaves. This research was an experimental study with completely randomized design. There were 4 times repetition in 4 formulas, one control formula (F0) and 3 modified formulas (F1, F2, F3). Data was analyzed by Friedman and Wilcoxon Test $(\alpha=0.05)$. The result of sensory evaluation showed that the syrup was generally accepted and liked by the panelists (colour, flavour, texture, and taste). The taste of the formula 1 (FI) was more acceptable than others. Statistical analysis showed that there was no significant on differences colour between formulas. Meanwhile flavors, texture and taste between formulas ( $\alpha$ 0.05). Syrup made of Averrhoa bilimbi L and Ficus carica L leaves are recommend as a functional food with flavonoid content of $0.233 \%$ per $100 \mathrm{ml}$ syrup or $233 \mathrm{mg}$. This flavonoid content which can fulfill the flavonoid requirement in either healthy condition or hypercholestrolemia.
\end{abstract}

Keywords: Averrhoa bilimbi L, Ficus carica L leaves, sensory evaluation, flavonoid, syrup

Vetty S.M., dan Annis C.A. MGI (2018) 159-167

DOI: 10.20473/mgi.v13i2.159-167 


\section{PENDAHULUAN}

Era globalisasi dan modernisasi mengakibatkan perubahan gaya hidup masyarakat. Perubahan yang terjadi diantaranya adalah pola makan. Masyarakat cenderung memilih hal-hal yang cepat dan makanan serta mengandung tinggi lemak.

Padatnya aktivitas mereka juga berpengaruh pada penurunan aktivitas berolah raga. Efek samping yang dapat ditimbulkan dari perilaku tersebut seperti kanker, diabetes militus, hipertensi, stroke, aterosklerosis, katarak, dan penyakit jantung koroner (PJK) (Kopin dan Lowenstein, 2010). Salah satu penyebab timbulnya penyakitpenyakit degeneratif tersebut adalah karena kelebihan kolesterol dalam tubuh.

Kolesterol dalam tubuh sebagian besar berasal dari makanan yang mengandung tinggi lemak. Konsumsi lemak berlebihan akan meningkatkan jumlah kolesterol dan trigliserida dalam darah. Oksidasi keduanya menyebabkan pembentukan radikal bebas yang diketahui dapat merusak sel endotel dan mengakibatkan aterosklerosis. Sindrom ini dapat memengaruhi pembuluh darah arteri, respons peradangan kronis pada dinding arteri, dan sebagian besar akumulasi sel darah putih pada makrofag. Kondisi tersebut dapat menyebabkan terjadinya pengerasan arteri yang dapat menghambat aliran darah arteri sehingga mengakibatkan serangan jantung dan stroke (Charlton-Menys dan Durrington, 2006; Lakshmi et al., 2012).

Kematian akibat Penyakit Tidak Menular (PTM) mencapai 38 juta jiwa tiap tahunnya, jenis PTM yang sering menyebabkan kematian adalah PJK (46,4\%), kanker (21,7\%), hipertensi (12,8\%), dan diabetes $40 \%$. Pada penelitian Interheart yang dilakukan Bull dan Morrel pada tahun 2007 di 52 negara yang melibatkan 30.000 orang menunjukkan bahwa hampir 50\% serangan jantung dapat dikaitkan dengan kadar kolestrol darah yang abnormal.

World Health Organization (WHO) pada tahun 2011 memperkirakan 17 juta orang meninggal akibat penyakit jantung setiap tahunnya, yaitu sama dengan $30 \%$ total kematian di dunia atau 7 juta lebih kematian disebabkan oleh PJK. Terjadinya penyakit atau kondisi tersebut bisa dipengaruhi adanya stress oksidatif yang menghasilkan radikal bebas berlebih yang dapat mengganggu kesehatan. Maka dari itu diperlukan antioksidan untuk mengatasi stress oksidatif dan radikal bebas yang ada dalam tubuh (Winarsi, 2007).

Tubuh manusia secara alami memiliki sistem antioksidan untuk menangkal radikal bebas yaitu antioksidan endogen namun jika radikal bebas berlebih maka tubuh membutuhkan antioksidan eksogen seperti flavonoid, statin, niacin, dan lain-lain (Reynetson et al., 2005; Meydani, 2000; Werdhasari, 2014). Pola hidup kurang sehat yang dilakukan masyarakat modern seperti mengonsumsi makanan berbahan kimia, serta kondisi lingkungan dengan tingkat polusi udara yang tinggi akibat dari asap kendaraan, maka radikal bebas dalam tubuh menjadi berlebih (Winarti, 2010) yang bisa memperparah kondisi kesehatan.

Ketika jumlah radikal bebas melebihi kondisi normal, maka tubuh memerlukan konsumsi bahan makanan yang mengandung antioksidan. Menurut Erguder et al. (2007) Kebutuhan akan antioksidan tambahan tersebut bisa dipenuhi dengan mengonsumsi makanan sumber flavonoid, vitamin C, vitamin E, dan karotin. Asupan flavonoid sejumlah $50-50 \mathrm{mg} /$ hari diperlukan setiap orang guna mempertahankan kesehatan yang optimal (Masruhen, 2010). Sedangkan untuk pencegahan PTM membutuhkan minimal asupan flavonoid 199,6 mg/ hari (Holick et al., 2002).

Flavonoid merupakan salah satu kandungan metabolit sekunder terbanyak yang dikonsumsi manusia sebagai antioksidan yang bersifat melawan radikal bebas, dan terbukti mampu menurunkan risiko PTM. Penelitian pada subjek berusia $\geq 19$ tahun menunjukkan asupan flavonoid mampu menurunkan risiko kanker 41\%, PJK 18\%, hipertensi $9 \%$, DM $8 \%$, gagal jantung 19\%, dan stroke 10\% (Mc Cullough et al., 2012; Cassidy et al., 2012).

Belimbing wuluh dengan nama latin Averrhoa bilimbi $L$ dan tanaman tin dengan nama latin Ficus carica L, kedua tanaman terbukti bermanfaat bagi kesehatan dan digunakan sebagai obat tradisional (Siddique et al., 2013; Patil dan Patil, 2011). Kandungan kimia belimbing wuluh terdiri atas saponin, flavonoid, tanin, glukosida, asam format, dan lainnya (Dalimartha, 2008). 
Tanaman tin (Ficus carica L) memiliki berbagai khasiat seperti mengobati penyakit metabolik, kardiovaskular, pernapasan, antispasmodic, anti inflamasi, antioksidan, antikanker, hepatoprotektif, antibakterial (Duke et al., 2005; Mawa, 2013). Semua bagian tanaman tin memiliki manfaat terutama bagian daun yang diketahui memiliki banyak senyawa bioaktif seperti $\beta$-sitosterol, saponin, flavonoid dan tanin. Daun tin mengandung cukup banyak flavonoid, sehingga berpotensi untuk dijadikan obat (Joseph dan Raj, 2011; Vaya dan Mahmood, 2006).

Salah satu olahan belimbing wuluh yang beredar dipasaran adalah sirup. Menurut Winarno (2006), sirup yang beredar selama ini lebih dominan pada minuman atau bahan pangan yang tinggi gula dengan kandungan paling sedikit 50\% sukrosa. Maka dalam penelitian ini dibuatlah sirup dengan kombinasi belimbing wuluh (Averrhoa bilimbi L) dan daun tin (Ficus carica L) dengan tujuan menjadikan sirup lebih bermanfaat untuk kesehatan karena mengandung senyawa flavonoid yang baik untuk antioksidan tubuh.

\section{METODE}

Penelitian ini merupakan eksperimental dengan dua tahap yaitu tahap pengembangan formula sirup dan tahap uji organoleptik. Desain penelitian yaitu eksperimental murni menggunakan Rancangan Acak Lengkap (RAL) dengan 4 perlakuan dan 4 kali pengulangan. Perlakuan merupakan penambahan daun tin yang berbeda pada formula sirup yaitu formula kontrol (F0) tanpa daun tin, formula modifikasi 1 (F1) dengan penambahan $100 \mathrm{~g}$ daun tin, formula modifikasi 2 (F2) dengan penambahan $150 \mathrm{~g}$ daun tin, dan formula modifikasi 3 (F3) dengan penambahan $250 \mathrm{~g}$ daun tin.

Pada tahap pengembangan formula didapatkan tiga formula modifikasi untuk diujikan secara organoleptik pada panelis tidak terlatih yaitu orang dewasa sehat, tidak memiliki gangguan pada indera penglihatan, perasa, penciuman, dan peraba, sejumlah 33 orang. Penelitian ini telah mendapatkan persetujuan dari Komisi Etik Penelitian Kesehatan No. 268-KEPK.
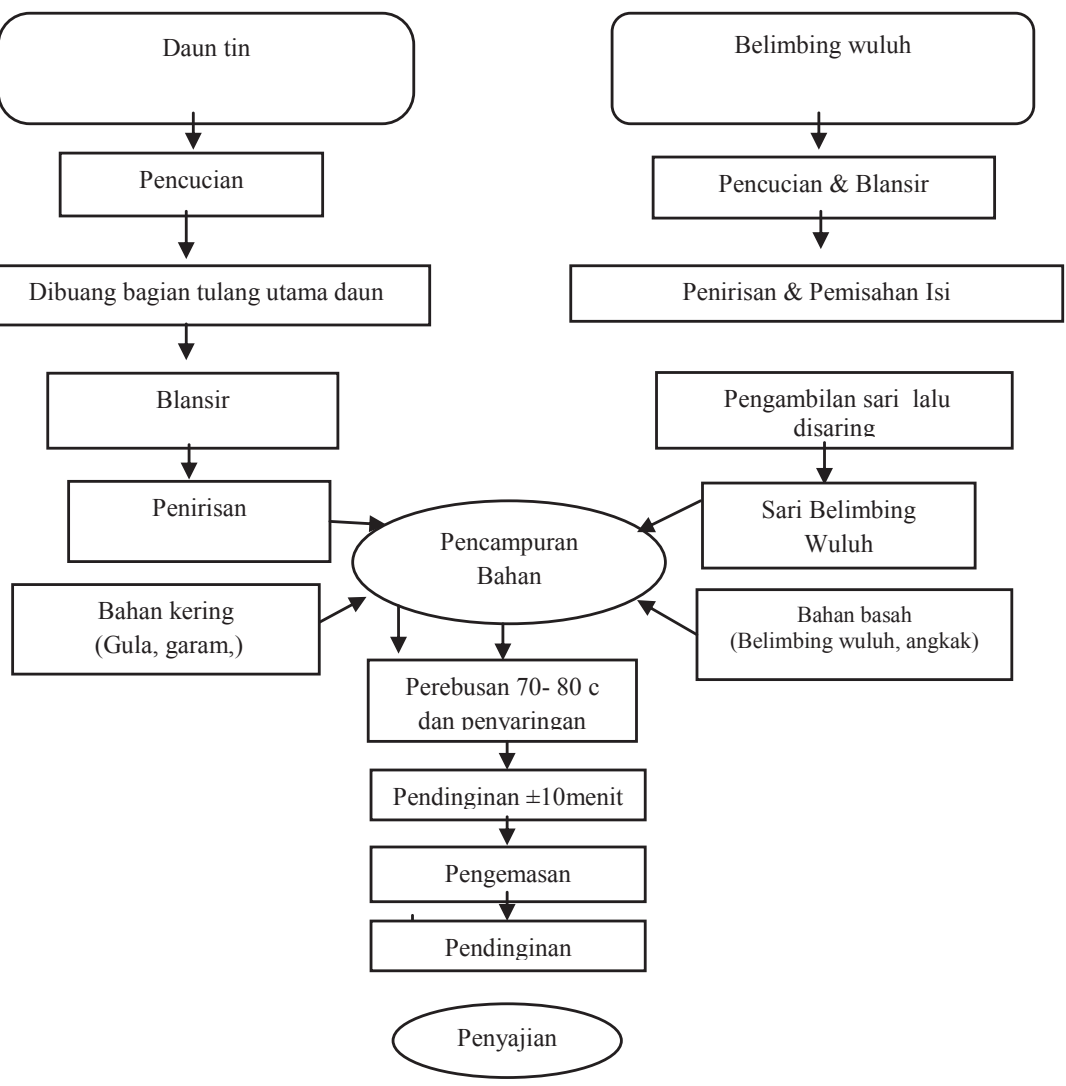

Gambar 1. Pembuatan Sirup Belimbing Wuluh Diperkaya Daun Tin 
Tabel 1. Formula Sirup

\begin{tabular}{lcccc}
\hline \multicolumn{1}{c}{ Formula/g } & F0 & F1 & F2 & F3 \\
\hline Belimbing wuluh & 500 & 500 & 500 & 500 \\
Gula & 325 & 325 & 325 & 325 \\
Angkak & 30 & 30 & 30 & 30 \\
Daun tin & 0 & 100 & 150 & 250 \\
Total & 855 & 955 & 1005 & 1105 \\
\hline
\end{tabular}

Data dianalisis secara statistik menggunakan uji non-parametrik Friedman dan jika terdapat perbedaan signifikan maka untuk mengetahui pasangan yang berbeda menggunakan uji wilcoxon rank dengan $\alpha=0,05$. Penentuan formula terbaik diambil dari nilai rata-rata tertinggi dari keseluruhan daya terima sirup. Peralatan yang digunakan pada penelitian ini adalah timbangan, gunting, pengaduk, panci, juicer, mug, penyaring kain, botol, dan seperangkat alat uji organoleptik serta angket uji. Semua peralatan yang digunakan sama untuk semua perlakuan. Dalam penelitian ini. Bahan sirup yang digunakan dalam penelitian ini meliputi buah belimbing wuluh (Averrhoa bilimbi $L$ ), gula, angkak, dan daun tin (Ficus carica L).

Belimbing wuluh didapatkan dari area perkampungan wilayah Kecamatan Gubeng, Surabaya, daun tin didapatkan dari tempat budidaya daun tin di Kabupaten Gresik, serta bahan lain seperti gula didapatkan di toko bahan pokok, dan angkak didapatkan dari toko obat tradisional. formulasi yang dilakukan dengan penambahan daun tin disajikan pada tabel 1.

\section{Pembuatan Sirup}

Tahap pertama belimbing wuluh (Averrhoa bilimbi L) dihancurkan dengan juicer extractor kemudian disaring dengan kain saring untuk mendapatkan air sarinya. Tahap kedua sari belimbing wuluh, gula, daun tin, angkak dimasak jadi satu dengan proporsi sari belimbing wuluh:gula adalah 2:1.

Selanjutnya diaduk hingga mendidih dengan suhu $70-80^{\circ} \mathrm{C}$. Tahap ketiga pendinginan \pm 10 menit kemudian disaring dengan kain saring pada mug dan didiamkan lagi \pm 10 menit kemudian disaring dengan kain saring terakhir dimasukkan dalam botol dan ditutup rapat. Satu formula uji menghasilkan $600 \mathrm{ml}$ sirup.

\section{Uji Organoleptik}

Pengujian organoleptik dilakukan dengan tujuan menilai karakteristik warna, aroma, tekstur (kekentalan), dan rasa sirup, dengan diberi kode berupa angka F0 (715), F1 (224), F2 (033), dan F3 (551), dan disajikan secara acak kepada 33 panelis tidak terlatih yang merupakan orang dewasa sehat, tidak memiliki gangguan pada indera penglihatan, perasa, penciuman, dan peraba.

Penyajian dilakukan menggunakan cup dengan isi $30 \mathrm{ml}$ sirup bercampur air (dengan pengenceran 1:3) dan diberi air mineral yang dikonsumsi setiap selesai mencicip 1 sampel sirup dengan tujuan untuk menetralkan indera pengecap. Skala penilaian menggunakan 3 kategori untuk memudahkan panelis dalam menilai dan menghindari bias, dengan kategori $1=$ tidak suka, 2 = agak suka, dan 3 = suka.

\section{Analisa Senyawa Flavonoid}

Sirup belimbing wuluh (Averrhoa bilimbi $L$ ) dengan kombinasi daun tin (Ficus carica L) terdiri dari empat formula sirup (Tabel 1). Analisa laboratorium dilakukan pad formula terbaik yang terpilih berdasarkan penilaian tertinggi pada uji organoleptik menggunakan metode Gas Chromatogaf (GC).

\section{HASIL DAN PEMBAHASAN}

Uji organoleptik dilakukan untuk mengetahui apakah produk sirup belimbing wuluh (Averrhoa bilimbi L) dan daun tin (Ficus carica L) dapat diterima oleh konsumen. Dari hasil uji organoleptik dapat menunjukkan formula mana yang paling disukai oleh panelis sehingga dari keempat formula sirup didapatkan satu produk terbaik berdasarkan penilaian daya terimanya. Hasil dari uji organoleptik berupa nilai rata-rata kesukaan panelis yang meliputi penilaian warna, aroma, tekstur (kekentalan), dan rasa dapat dilihat pada tabel 2. Penilaian organoleptik sirup secara umum panelis memberikan penilaian yang beragam dari agak suka hingga suka pada keempat formula sirup.

Hal ini menunjukkan formula sirup masih dapat diterima oleh panelis terutama untuk 
Tabel 2. Hasil Uji Organoleptik Sirup Kombinasi Belimbing Wuluh dan Daun Tin

\begin{tabular}{|c|c|c|c|c|c|c|c|c|c|c|c|}
\hline \multirow{3}{*}{ Formula } & & \multicolumn{6}{|c|}{ Penilaian } & \multirow{2}{*}{\multicolumn{2}{|c|}{ Total }} & \multirow{3}{*}{ Mean rank } & \multirow{3}{*}{ Pvalue } \\
\hline & & \multicolumn{2}{|c|}{1} & \multicolumn{2}{|c|}{2} & \multicolumn{2}{|c|}{3} & & & & \\
\hline & & $\mathrm{n}$ & $\%$ & $n$ & $\%$ & $\mathrm{n}$ & $\%$ & $\mathbf{N}$ & $\%$ & & \\
\hline \multirow{4}{*}{ Warna } & F0 & 3 & 9,1 & 22 & 66,7 & 8 & 24,2 & 33 & 100 & 1,9 & \multirow{4}{*}{0,174} \\
\hline & $\mathrm{F} 1$ & 3 & 9,1 & 19 & 57,6 & 11 & 33,3 & 33 & 100 & 2,2 & \\
\hline & F2 & 4 & 12,1 & 19 & 57,7 & 10 & 30,3 & 33 & 100 & 2,2 & \\
\hline & F3 & 4 & 12,1 & 16 & 48,5 & 13 & 39,4 & 33 & 100 & 2,3 & \\
\hline \multirow{4}{*}{ Aroma } & F0 & 11 & 33,3 & 12 & 36,4 & 10 & 30,3 & 33 & 100 & 2,0 & \multirow{4}{*}{0,022} \\
\hline & $\mathrm{F} 1$ & 4 & 12,1 & 18 & 54,5 & 11 & 33,3 & 33 & 100 & 2,2 & \\
\hline & F2 & 6 & 18,1 & 17 & 51,5 & 10 & 30,3 & 33 & 100 & 2,1 & \\
\hline & F3 & 4 & 12,1 & 16 & 48,5 & 13 & 39,3 & 33 & 100 & 2,3 & \\
\hline \multirow{4}{*}{ Kekentalan } & F0 & 9 & 27,3 & 15 & 45,4 & 9 & 27,3 & 33 & 100 & 2,0 & \multirow{4}{*}{0,004} \\
\hline & $\mathrm{F} 1$ & 8 & 24,2 & 17 & 51,5 & 8 & 24,2 & 33 & 100 & 2,0 & \\
\hline & F2 & 6 & 18,2 & 16 & 48,5 & 11 & 33,3 & 33 & 100 & 2,1 & \\
\hline & F3 & 5 & 15,1 & 16 & 48,5 & 12 & 36,7 & 33 & 100 & 2,2 & \\
\hline \multirow{4}{*}{ Rasa } & F0 & 4 & 12,1 & 14 & 42,4 & 15 & 45,4 & 33 & 100 & 1,9 & \multirow{4}{*}{0,001} \\
\hline & F1 & 6 & 18,2 & 9 & 27,3 & 18 & 54,5 & 33 & 100 & 2,9 & \\
\hline & F2 & 2 & 6,1 & 14 & 42,4 & 17 & 51,5 & 33 & 100 & 1,9 & \\
\hline & F3 & 7 & 21,2 & 12 & 36,4 & 14 & 42,4 & 33 & 100 & 2,2 & \\
\hline
\end{tabular}

Keterangan:

$1=$ Tidak suka $; 2=$ Agak suka $; 3=$ Suka

$P$ value : Uji Friedman

formula modifikasi 1 atau F1 yang mempunyai nilai rata-rata lebih tinggi dibandingkan formula modifikasi lainnya. Sedangkan untuk penerimaan formula kontrol (F0) masih dibawah F1 namun tetap disukai oleh panelis. Dari hasil penilaian organoleptik diketahui bahwa penambahan daun tin pada sirup belimbing wuluh memberikan penerimaan sensori yang berbeda pada konsumen. Adanya penambahan daun tin pada sirup belimbing wuluh, meningkatkan penerimaannya. Aroma dan rasa khas dari daun tin yang ditambahkan pada sirup dapat meningkatkan kesukaan panelis. Hasil tersebut sejalan dengan penelitian Dewi (2016) pada minuman herbal dari ekstrak belimbing wuluh yang ditambahkan ekstrak kulit buah naga dan daun stevia.

\section{Warna}

Penilaian organoleptik terhadap warna sirup belimbing wuluh dan daun tin menunjukkan bahwa warna memengaruhi penerimaan sirup. Hasil penilaian organoleptik pada tabel 2 dapat diketahui bahwa penilaian tertinggi pada karakteristik warna terdapat pada formula modifikasi 3 (F3). Rata-rata penilaian kesukaan terhadap warna berada pada skala 1,90-2,27 yang termasuk dalam kategori agak suka. Sirup dengan penambahan daun tin memiliki warna oranye yang gelap, berbeda dengan sirup kontrol (F0) yang memiliki warna oranye yang cenderung muda bening. Seiring ditambahkannya daun tin, maka warna oranye yang dihasilkan menjadi semakin gelap karena kandungan klorofil didalam daun tin sehingga produk sirup menjadi lebih menarik (Towaha et al., 2013).

Warna merupakan rangsangan pertama pada indera melihat yang memengaruhi penerimaan makanan (Dewi, 2016). Warna sirup pada formula F0 merupakan warna sirup yang agak disukai oleh panelis Panelis cenderung menyukai warna formula F3 daripada F0 dikarenakan warna yang dihasilkan lebih menarik Hasil uji Friedman menunjukkan bahwa penambahan daun tin tidak berpengaruh $(p=0,174)$ terhadap warna sirup. Artinya warna sirup F1 tidak berbeda nyata dengan warna sirup F2 dan F3.

\section{Aroma}

Aroma menjadi penentu kelezatan suatu makanan. Suatu produk pangan akan lebih mudah diterima oleh konsumen jika memiliki aroma yang khas dan menarik (Winarno, 2006). Penilaian organoleptik terhadap aroma sirup menunjukkan bahwa dari segi aroma, sirup belimbing wuluh 
Tabel 3. Uji Wilcoxon Aroma

\begin{tabular}{ccc}
\hline Sirup & p value & Keterangan \\
\hline F1\&F2 & 0,083 & Tidak ada beda \\
F1\&F3 & 0,157 & Tidak ada beda \\
F2\&F3 & 0,025 & Ada beda \\
\hline
\end{tabular}

dengan daun tin masih dapat diterima oleh konsumen dengan rata-rata penilaian 1,962,27 seperti pada tabel 3. Aroma dari formula F3 menjadi yang paling disukai oleh panelis, sedangkan aroma pada formula sirup F2 memiliki penerimaan yang rendah dibandingkan dengan formula F1 dan F3.

Hasil uji Friedman menunjukkan nilai yang signifikan $(p=0,022)$. Hal ini berarti terdapat perbedaan daya terima aroma sirup antara formula. Oleh karena itu, dapat dikatakan bahwa penambahan daun tin berpengaruh nyata terhadap aroma sirup belimbing wuluh. Sejalan dengan hasil penelitian Triswandari (2006) pada minuman belimbing wuluh dan jahe menunjukkan bahwa pencampuran jahe menyebabkan perbedaan nyata pada tingkat kesukaan aroma dengan aroma yang disukai yaitu pada penambahan jahe yang lebih banyak karena adanya aroma khas dari jahe yang disukai. Jahe dan daun tin memiliki kekhasan aroma masing-masing, sehingga ketika ditambahkan dalam produk sirup bimbing wuluh dapat meningkatkan kesukaan panelis terhadap aroma.

Berdasarkan hasil uji wilcoxon pada tabel 3 , tidak terdapat perbedaan aroma yang nyata antara formula F1 dengan F2 dan F3 sementara itu terdapat perbedaan yang nyata antar aroma F2 dengan $\mathrm{F} 3(\mathrm{p}=0,025)$.

Apabila dibandingkan dengan formula sirup kontrol (F0), aroma sirup dengan penambahan daun tin lebih disukai oleh panelis dilihat dari uji wilcoxon rank. Kesukaan yang tinggi terhadap aroma sirup pada formula modifikasi 3 (F3) dapat disebabkan karena adanya percampuran aroma khas daun tin dalam formula sirup. Aroma yang dihasilkan oleh F3 terasa lebih kuat dibandingkan dengan aroma F0 yang hanya berbau belimbing wuluh. Sirup belimbing wuluh memiliki aroma yang langu sehingga perlu dilakukan penambahan bahan lain untuk menyamarkan aroma langu tersebut.
Tabel 4. Uji Wilcoxon Kekentalan

\begin{tabular}{ccc}
\hline Sirup & p value & Keterangan \\
\hline F1\&F2 & 0,025 & Ada beda \\
F1\&F3 & 0,008 & Tidak Ada beda \\
F2\&F3 & 0,157 & Ada beda \\
\hline
\end{tabular}

\section{Kekentalan}

Penilaian kesukaan tertinggi pada karakteristik tekstur (kekentalan) terdapat pada formula modifikasi 3 (F3). Rata-rata penilaian kesukaan terhadap tekstur (kekentalan) berada pada skala 2,00-2,21 yang termasuk dalam kategori agak suka sampai suka. Tekstur produk sirup dinilai dari sifat kekentalan yang dapat dirasakan oleh panelis dengan indera peraba dan pengecap.

Penilaian organoleptik terhadap tekstur sirup menunjukkan bahwa dari segi tekstur sirup belimbing wuluh dan daun tin masih dapat diterima oleh masyarakat. Tekstur sirup yang paling disukai oleh panelis adalah tekstur pada formula sirup F3. Apabila dibandingkan dengan formula kontrol, tekstur sirup dengan daun tin lebih disukai oleh panelis. Hasil uji Friedman menunjukkan adanya perbedaan signifikan $(p=0,004)$, sehingga dapat dikatakan bahwa penambahan daun tin (Ficus carica L) pada sirup belimbing wuluh (Averrhoa bilimbi $L$ ) memengaruhi tekstur sirup.

Berdasarkan hasil uji Wilcoxon pada tabel 4 didapatkan hasil bahwa antara tekstur F1 dengan F2 dan F3 memiliki perbedaan yang nyata, sedangkan tekstur F2 dan F3 tidak memiliki perbedaan. Apabila dibandingkan dengan formula sirup kontrol (F0), tekstur sirup dengan penambahan daun tin lebih disukai oleh panelis. Kesukaan tekstur tertinggi pada sirup pada formula modifikasi 3 (F3). Sirup Formula F3 lebih disukai karena tekstur kekentalan yang pas dengan tidak terlalu kental dan tidak terlalu cair.

\section{Rasa}

Hasil uji organoleptik menunjukkan bahwa sirup belimbing wuluh (Averrhoa bilimbi L) dan daun tin (Ficus carica L) masih dapat diterima oleh masyarakat meskipun sebagian sirup tidak begitu disukai oleh panelis. Penilaian kesukaan tertinggi pada karakteristik rasa terdapat pada formula modifikasi 1 (F1). Rata-rata penilaian kesukaan 
Tabel 5. Uji Wilcoxon Rasa

\begin{tabular}{ccc}
\hline Sirup & p value & Keterangan \\
\hline F1\&F2 & 0,180 & Tidak Ada beda \\
F2\&F3 & 0,025 & Ada beda \\
F1\&F3 & 0,005 & Ada beda \\
\hline
\end{tabular}

terhadap rasa berada pada skala 1,87-2,86 (agak suka-suka) seperti pada tabel 2. Sirup yang paling disukai oleh panelis adalah sirup formula F1, sedangkan sirup yang kurang disukai ada pada formula (F2).

Sirup dengan penambahan daun tin lebih disukai oleh panelis dibandingkan dengan formula kontrol. Sejalan dengan hasil penelitian (Triswandari, 2006) pada minuman belimbing wuluh dan jahe bahwa pencampuran kedua bahan menyebabkan perbedaan nyata pada tingkat kesukaan rasa. Tingkat kesukaan yang tinggi formula sirup F1 oleh panelis disebabkan karena sedikitnya daun tin $(100 \mathrm{~g})$ yang ditambahkan dalam formula sirup sehingga rasa langu dan pahit dari daun tin dapat tertutupi oleh rasa asam dan manis dari belimbing wuluh dan gula. Tingkat kesukaan yang rendah pada formula sirup F2 oleh panelis disebabkan karena perpaduan bahan yang kurang disukai panelis.

Hasil uji Friedman menunjukkan bahwa penambahan daun tin pada sirup belimbing wuluh berpengaruh nyata $(\mathrm{p}=0,001)$. Uji lanjut Wilcoxon menunjukkan bahwa formula $\mathrm{F} 3$ berbeda nyata dengan formula F1 dan F2. Sedangkan pasangan
Tabel 6. Kandungan Sirup Flavanoid $(\mathrm{mg} / 100 \mathrm{~mL})$

\begin{tabular}{cc}
\hline Formula & Kandungan $(\mathbf{m g} / \mathbf{1 0 0} \mathbf{m L})$ \\
\hline F0 & 7,3 \\
F1 & 5,8 \\
F2 & 9,4 \\
F3 & 5,5 \\
\hline
\end{tabular}

Sumber: BPKI (Balai Penelitian dan Konsultasi Industri)

formula F1 dan F2 tidak berbeda. Seperti pada tabel 5. Perbedaan tersebut dipengaruhi oleh rasa khas dari kedua bahan, dimana belimbing wuluh memiliki rasa asam dan daun tin memiliki rasa pahit.

\section{Kadar Flavonoid}

Kadar Flavonoid sirup dianalisis dengan perhitungan secara empiris menggunakan hasil penelitian sebelumnya dan analisis laboratorium pada formula yang paling disukai rasanya oleh panelis yaitu formula F1. Hasil analisis empiris ditampilkan dalam tabel 6 .

Berdasarkan hasil perhitungan dan laboratorium sirup dengan porsi atau takaran 100 $\mathrm{ml}$ dapat memenuhi kebutuhan flavonoid baik untuk kebutuhan kondisi kesehatan maupun pada kondisi pengobatan atau pencegahan penyakit degeneratif salah satunya hiperkolesterolemi dan PJK.

Berdasarkan hasil laboratorium didapatkan bahwa dalam $100 \mathrm{ml}$ sirup belimbing wuluh dan

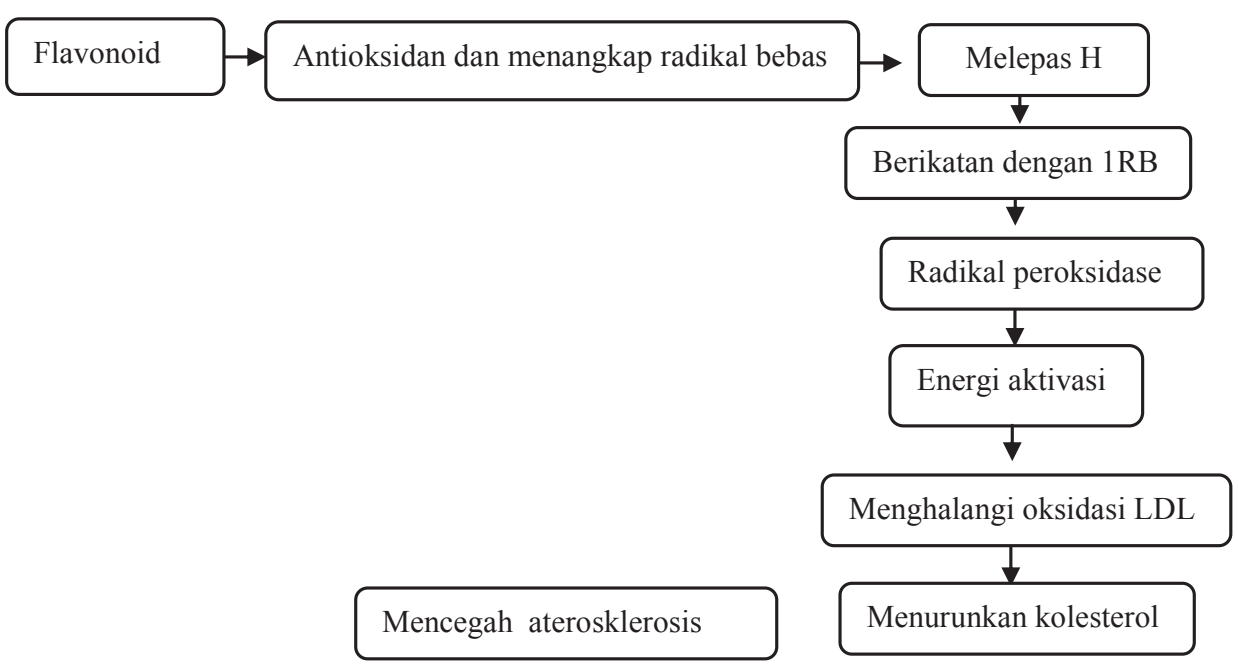

Gambar 2. Mekanisme aksi penurunan kadar kolesterol (Winarsi, 2007) 
daun tin terdapat flavonoid $0,233 \%$ yang artinya terdapat $233 \mathrm{mg}$ flavonoid dalam $100 \mathrm{ml}$ sirup. Jika dibandingkan dengan kebutuhan sehari-hari yang hanya 50-150 mg dan kebutuhan maintenance atau pencegahan PTM seperti hiperkolesterolemi dan PJK sebesar 199,6 mg (Holick et al., 2002).

Kandungan flavonoid dalam sirup ini dapat mencukupi kebutuhan tubuh. Untuk dikonsumsi sehari-hari sirup belimbing wuluh ditambahkan daun tin dapat dikonsumsi 5-10 sendok makan sirup kemudian diencerkan dengan air dengan perbandingan minimal 1:3 berdasarkan studi pendahuluan. Mekanisme pencegahan flavonoid dari kolesterol tubuh dan radikal bebas dalam tubuh dapat digambarkan pada gambar 2 .

Hasil analisis kadar Flavonoid laboratorium dengan analisa BPKI, memiliki perbedaan dan terdapat kenaikan kandungan flavonoid. Hal tersebut bisa disebabkan oleh adanya penambahan pewarna dari angkak yang menyumbang sebesar $114,3 \mathrm{mg}$ flavonoid dalam $30 \mathrm{~g}$ angkak yang dicampurkan dalam satu formula, serta dapat dimungkinkan adanya perbedaan metode pengujian yang dilakukan antara hasil laboratorium BPKI dan hasil yang dilaporkan pada penelitian ini. Pemilihan formula terbaik sirup dilihat dari rata-rata daya terima secara keseluruhan dari segi warna, aroma, tekstur dan rasa. Hasil uji organoleptik pada tabel 2 menunjukkan bahwa formula F1 memiliki penerimaan paling tinggi terutama pada karakteristik rasa jika dibandingkan dengan formula F2 dan F3 sehingga formula sirup yang direkomendasikan adalah formula F1.

\section{KESIMPULAN DAN SARAN}

Hasil dari penilaian uji organoleptik sirup belimbing wuluh (Averrhoa bilimbi L) dengan penambahan daun tin (Ficus carica L) masih dapat diterima oleh masyarakat serta mengandung senyawa aktif flavonoid yang lebih tinggi dibandingkan pada sirup belimbing wuluh saja. Dari keempat formula yang disukai formula F1 (100 g daun tin).

Tidak ada perbedaan signifikan antara daya terima sirup formula terbaik (F1) dengan formula kontrol (F0). Sirup formula terbaik dalam 100 $\mathrm{ml}$ mengandung $233 \mathrm{mg}$ flavonoid yang dapat memenuhi kebutuhan antioksidan flavonoid sehari. Formula sirup belimbing wuluh (Averrhoa bilimbi L) kombinasi daun tin (Ficus carica L) dapat direkomendasikan sebagai minuman fungsional dengan kandungan flavonoid yang berguna bagi tubuh sebagai antioksidan. Perlu adanya pengembangan lebih lanjut terhadap formulasi agar dapat meningkatkan daya terima warna, rasa, aroma, dan tekstur.

\section{DAFTAR PUSTAKA}

Bull, E., \& Jonathan, M., (2007). Kolesterol. Jakarta: Erlangga.

Cassidy, A., Rimm, EB., O’Reilly, E.J., Logoscino, G., Kay, C., Chiuve, S.E., \& Rexrode, K.M., (2012). Dietary flavonoids and risk of stroke in women. Stroke. 43:946-951.

Charlton-Menys, V., \& Durrington, P.N. (2007). Human cholesterol metabolism and therapeutic molecules. Exp Physiol 93 (1): 27-42.

Dalimartha, S. (2008) Belimbing wuluh (Averrhoa bilimbi). Dalam: Dahlianti R, penyunting. Atlas tumbuhan obat Indonesia. Edisi ke-5. Jakarta: Pustaka Bunda; 2008. hlm. 6-10.

Dewi, R, \& Suparti. (2016). Aktivitas antioksidan dan uji organoleptik minuman herbal ektrak belimbing wuluh dengan kombinasi ekstrak kulit buah naga merah. Universitas muhammadiyah Surakarta, Jawa Barat.

Duke, J.A., Bugenschutzgodwin, M.J, Ducollier, J, \& Duke, P.K. (2005). Hand book of medicinal herbs, 2nd ed, CRC Press, Boca Raton, Fla, USA.

Erguder, B., Avci, A., Devrim, E. \& Durak, I. (2007). Effects of cooking techniques on antioxidant enzyme activities of some fruits and vegetables. Turk. J. Med.Sci., 37(3):151-156

Holick, C.N., Michaud, D.S., Stolzanberg-solomon, R., Mayne, S.T., Pietinen, P., Taylor, P.R., Vrtamo, J., \& Albanes, D. (2002). Dietary carotenoids, serum $\beta$-carotene, and retinol and risk of lung cancer in the alpha-tocopherol, beta-carotene cohort study. American Journal of Epidemiology. 156 (6): 536-547

Joseph, B., \& Raj, J.S. (2011). Pharmacognostic and phytochemical properties of Ficus carica 
Linn -An overview. International Journal of PharmTech Research. ISSN: 0974-4304. Vol. 3, No.1, pp. 08-12.

Kopin, L., \& Lowenstein, C. (2010). In the clinic dyslipidemia. Ann Intern Med, 153(3): ITC21-ITC2-16.

Lakshmi, V., Mahdi, A.A., Agarwal, S.K., \& Khanna, A.K. (2012). Steroidal saponin from chlorophytum nimonii (gah) with lipid-lowering and antioxidant activity. Original article, 3:22732.

Masruhen. (2010). Pengaruh pemberian infus buah belimbing wuluh (averrhoa bilimbi 1.) terhadap kadar kolesterol darah tikus. Jurnal Farmasi. Universitas Muhamadiyah. Malang.

Mawa, S., Husain, K., \& Jantan, I. (2013). Ficus carica L. (Moraceae): Phytochemistry, traditional uses and biological activities. Evidence-Based Complementary and Alternative Medicine. Volume 2013, Article ID 974256.

McCullough, M.L., Peterson, J.J., Patel, R., Jacques, P.F., Shah, R., \& Dwyer, J.T. (2012). Flavonoid intake and cardiovascular disease mortality in a prospective cohort of US adults. Am J Clin Nutr. 95:454-64.

Meydani, M. (2000). Effect of functional food ingredient : Vitamin E

Patil, V.V., \& Patil, V.R. (2011a). Ficus carica Linn.an overview. Res J Med Plants. 5(3):246-253. doi: 10.3923/rjmp.2011.246.253.

Reynertson, K. A., Basile, M. J. \& Kennelly, E. J., (2005). Antioxidant potential of seven myrtaceous fruits, Ethnobotany Research \& Applications, 3:025035.
Siddique, K.T. Uddin, M.M., Islam, S. ,\& Shahriar, M. (2013). Phytochemical screening, thrombolytic activity and anti microbial properties of the bark extracts of averrhoa bilimbi. J App Pharm. Sci., 3 (03), 094-096.

Towaha, \& Bali, T. (2103). Kandungan senyawa kimia pada daun teh (camellia sinensis). Warta Penelitian Dan Pengembangan Tanaman Industri, Volume 19 Nomor 3.

Triswandari N, (2006). Pembuatan minuman belimbing wuluh (averrhoa bilimbi l)-jahe (zinger officinale) dan pengujian stabilitasnya selama penyimpanan. Institut Teknologi Bogor, Fakultas Ilmu Teknologi Pertanian, Bogor.

Vaya, J., \& Mahmood, S. (2006). Kandungan flavonoid dalam ekstrak daun ara (Ficus carica L.), carob (Ceratonia siliqua L.) dan pistachio (Pistacia lentiscus L.). Biofactors, 28, 169-175.

Werdhasari, A. (2014). Peran antioksidan bagi kesehatan. Pusat biomedis dan teknologi dasar. Balitbangkes Kemenkes RI.

Winarno, F.G. (2006). Kimia pangan dan gizi. Jakarta: Gramedia Pustaka Utama.

Winarsi, H., (2007). Antioksidan alami dan radikal bebas. Yogyakarta: Kanisius Hal. 6, 77-80, 1183.

Winarti, S. (2010). Makanan fungsional. Yogyakarta: www.kompas.co.id/ kesehatan/news/senior/ gizi/03

[WHO] World Health Organization. (2011). Global Status Report on. Diakses dari http://www.who. int/cardiovascular_diseases/en/. 